$4 \quad$ La Vega, L.T ${ }^{1}$; Sato, D².; Piza, L. V²; Costa, E. J. X ${ }^{*}$

5 preserving the birds' welfare, when compared with a single frequency system use.

\section{Effect of electrical hybrid-frequency waterbath stunning on the spontaneous electroencephalogram (EEG) and electrocardiogram (ECG) of broilers}

${ }^{1}$ F\&S Animal Origin Food Consulting, São Paulo - SP, Postal Code 04532-060

${ }^{2}$ Laboratory of Applied and Computational Physics, ZAB, FZEA, University of São Paulo Pirassununga/SP, Postal Code 13635-900 - e-mail: ernane@usp.br

\section{ABSTRACT}

Concerns about animal welfare and meat quality have encouraged research on new methods for the stunning of broilers during animal slaughter. In this study, the electroencephalogram (EEG) and electrocardiogram (ECG) of broilers were acquired during stunning using an electrical hybrid instead of a single frequency. Considering a square-wave with a current of $220 \mathrm{~mA}$ and a frequency of $1100 \mathrm{~Hz}$ (duty-cycle 50\%), the hybrid-frequency waveform is obtained generating pulses at 6600 Hertz in the pulse-width phase. Sixty broilers aged 42 days were randomly sampled; thirty were used for EEG measurement and thirty for ECG measurement. For EEG measurements, the birds' scalps were anaesthetized, and EEG electrode needles were inserted on the subcutaneous part of the occipital scalp. For ECG, the non-invasive surface electrode was used. The electrodes were connected to a digital EEG/ECG system. The results showed that the hybrid-frequency waveform system generated epileptic forms in the birds' EEGs. Therefore, a hybrid-frequency system may present better carcass quality results, while 


\section{INTRODUCTION}

27

Electrical stunning is the most common method for poultry stunning prior to slaughter, but it has been questioned on animal welfare and product quality grounds. The procedure consists of passing an electric current through the birds' brains with a magnitude sufficient to cause uncontrolled hyperpolarization of the neurons leading to unconsciousness (Berg and Raj, 2015). Animal welfare at the time of slaughter is under Regulation 1099/2009 of the European Union (European Union Council, 2009), and the regulation permits the use of different electrical stunning systems with electrical parameters that have been scientifically demonstrated. According to the regulation, water bath stunning shall be carried out for at duration of at least four seconds and with the minimum currents shown in Table 1. The World Organization for Animal Health (OIE) in its Terrestrial Animal Health Code (OIE 2019), has also recommended these electrical parameters.

Table 1 - Electrical requirements for water bath stunning equipment

\begin{tabular}{lllll}
\hline Frequency & Chickens & Turkeys & Ducks and geese & Quail \\
\hline$<200$ & $100 \mathrm{~mA}$ & $250 \mathrm{~mA}$ & $130 \mathrm{~mA}$ & $45 \mathrm{~mA}$ \\
From 200 to $400 \mathrm{~Hz}$ & $150 \mathrm{~mA}$ & $400 \mathrm{~mA}$ & Not permitted & Not permitted \\
From 400 to $1500 \mathrm{~Hz}$ & $200 \mathrm{~mA}$ & $400 \mathrm{~mA}$ & Not permitted & Not permitted \\
\hline
\end{tabular}

The electrical stunning equipment used to meet the aforementioned recommendations has a generator circuit that provides different waveforms, frequencies, and amplitudes of electrical currents. The equipment must have an automatic compensation circuit according to a bird's impedance variations in the slaughter line in order to deliver a constant current to each bird. However, because the high speed of lines, this compensation cannot be performed very accurately (Berg and Raj, 2015). 
Considering the guidelines of the European Union and OIE, along with the internationally designed requirements for humane slaughter, the objective of this study was to investigate electroencephalogram (EEG) and electrocardiogram (ECG) patterns of broilers

stunned with hybrid electrical current frequencies, instead of single frequencies, to evaluate

51 their impact on animal welfare. The experiment was conducted in the COPACOL 52 slaughterhouse company, located in city of Cafelândia, in the state of Paraná, Brazil. The study 53 was approved by the Ethics Committee on Animal Use (CEUA / USP-FZEA) under Protocol 54 CEUA n ${ }^{\circ} 4042150818$. The authors declare no conflict of interest.

MATERIAL AND METHODS

57

For ECG and EEG, a total of 60 broilers, ROSS line males with an average weight of $2.96 \mathrm{~kg}(\mathrm{std}=0.02)$ at 42 days-old, were used. Thirty broilers were used for EEG evaluation and 30 for ECG evaluation. Broilers were taken directly from the production line and brought to the experimental location created in the poultry sector of the COPACOL Company. Electronics - SC / Brazil), has selection waveforms for direct or alternating electric currents (DC/AC), a variable frequency of $20-3000 \mathrm{~Hz}$, duty cycle regulation from 10 to $90 \%$, an output voltage of 10-350 VRMS (Root Mean Square Voltage), and a couple of hybrid-frequency options. The electric current amplitude was registered with a True RMS digital multimeter model U1252B (Keysight Technologies ${ }^{\circledR}$ - USA), and the waveforms were monitored with a portable oscilloscope model H110-037 (HOMIS ${ }^{\circledR}$ - Brazil).

69 
bioRxiv preprint doi: https://doi.org/10.1101/2021 08.02.454822; this version posted August 5,2021 . The copyright holder for this preprint (which was not certified by peer review) is the author/funder, who has granted bioRxiv a license to display the preprint in perpetuity. It is made available under aCC-BY-NC-ND 4.0 International license.

\section{Electrical hybrid-frequency in animal welfare}

72 frequency of $1100 \mathrm{~Hz}$ (duty cycle 50\%), the hybrid frequency waveform was created by the

a graphical representation of hybrid waveform used in this study.

75

76

77

78

79

80 81 (Figure 2).

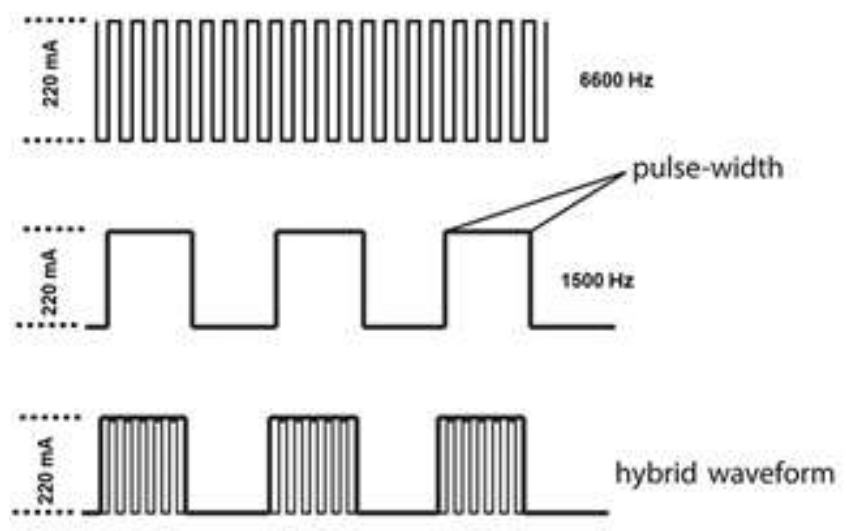

Figure 1-Graphical representation of hybrid frequency waveform used in the study $3 \mathrm{M}^{\circledR}$ model), self-adhesive ECG electrodes, which were adhered to cleaned skin overlying the pectoralis muscles on either side of the sternum, with a ground electrode under the right leg

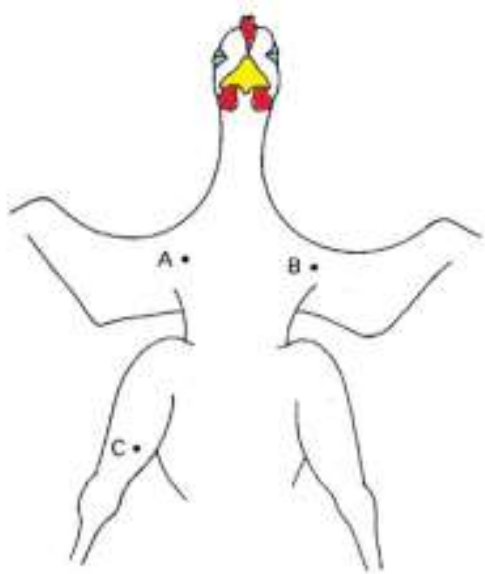


For the EEG measurements, the birds were individually implanted with needle electrodes (55\% silver, $21 \%$ copper, $24 \%$ zinc of $10 \mathrm{~mm}$ x $1.5 \mathrm{~mm}$ diameter - Neurosoft $^{\circledR}$ mod.

NS-NE-P-250/13/04) positioned under the skullcap, through the skin and skull onto the brain

lobes $(0.3 \mathrm{~cm}$ left and right of the sagittal suture and $0.5 \mathrm{~mm}$ toward an imaginary transverse

line at the caudal margin of the eyes), with one reference electrode placed on the right or left leg. The birds were anesthetized with lidocaine $(0.5 \mathrm{ml})$ applied subcutaneously on the same electrode areas, by using 31 gauge $\mathrm{BD}$ syringes (BD Ultra-Fine ${ }^{\mathrm{TM}}$ ). The electrodes were connected to the broilers with press-stud electrical connections.

To assess the EEG and ECG signals, each broiler was wrapped with a containment the wires from the electrodes and the EEG or ECG readers. The wrapped birds were placed on the slaughter line shackling and underwent the normal stunning process. The electrical water bath had the capacity for 12 birds at a time. As soon as the bird left the electrical water bath, the equipment (ECG/EEG) was automatically turned on, and the bird was taken off the line and and 60 seconds after the stunning process using wireless technology. successive artifact-free stretches were also analyzed and filtered using elliptical filters integrated into a visual tool developed at MATLAB ${ }^{\circledR}$. 


\section{RESULTS \& DISCUSSION}

The most important electrical parameters in electrical stunning are the current, voltage,

112 frequency, and resistance. The electrical current, measured in amperes (A), is defined as the

113 amount of electric charge flowing through a conductor. In electric circuits, this charge is carried

114 by electrons and ions in an electrolyte. The electric potential difference, known as voltage, is

115 the difference of electrical charge between two points, measured in volts (V). The electrical

116 impedance is the measure of the difficulty of an electric current to flow through a conductor,

117 and it is measured in ohms $(\Omega)$. In living tissues, a better term to define impedance is bio

118 impedance (Grimnes and Martinsen, 2015). These three electrical parameters are closely related

119 through Ohm's law (Eq.1):

$$
\mathrm{I}=\mathrm{V} / \mathrm{Z}=\frac{V}{|Z| e^{-1 \arg (z)}}
$$

$$
z=\operatorname{Re}\left\{\frac{(1-f) R e+(2+f)\left(R i-\frac{i}{\omega C m R a}\right)}{(1+2 f) R e+2(1-f)\left(R i-\frac{i}{\omega C m R a}\right)}\right\}
$$

where:

$\operatorname{Re}=$ resistivity of extracellular fluid $(\Omega \mathrm{cm})$

$$
\mathrm{Ri}=\text { resistivity of cytoplasm }(\Omega \mathrm{cm})
$$

$$
\mathrm{Cm}=\text { surface membrane capacity }\left(\text { Farads } / \mathrm{cm}^{2}\right)
$$

$$
\mathrm{Ra}=\text { cell radius }(\mathrm{cm})
$$


bioRxiv preprint doi: https://doi.org/10.1101/2021.08.02 454822; this version posted August 5,2021 The copyright holder for this preprint (which was not certified by peer review) is the author/funder, who has granted bioRxiv a license to display the preprint in perpetuity. It is made available under aCC-BY-NC-ND 4.0 International license.

A great variation in electrical parameters has been used in electric stunning studies

134 (Table 2). Even when the same frequency is used, for example, there are differences between 135 voltages and waveforms, as well as amplitudes of the electric current and times of shock 136 application. This fact may make direct result comparison challenging. According to Table 2, the parameters used in this study $(220 \mathrm{~mA} \pm 10 \mathrm{~mA}, 1100 \mathrm{~Hz}$ 138 (Duty Cycle 50\%)) to carry out the experiments have been applied previously in other studies.

139 Table 2 - Different waveforms, stun-time and current/voltage levels applied in electrical 140 stunning studies

\begin{tabular}{|c|c|c|c|c|c|}
\hline Study & $\begin{array}{c}\text { Voltage } \\
(\mathrm{V})\end{array}$ & Waveform & $\begin{array}{l}\text { Current } \\
(\mathrm{mA})\end{array}$ & $\begin{array}{l}\text { Frequency } \\
(\mathrm{Hz})\end{array}$ & $\begin{array}{c}\text { Time } \\
(\mathrm{s})\end{array}$ \\
\hline $\begin{array}{l}\text { (Gregory and } \\
\text { Wotton 1991) }\end{array}$ & NP & DC pulsed unipolar & $71-206$ & 350 & 4 \\
\hline (Craig and & NP & $\mathrm{AC}$ & 125 & 50 & 5 \\
\hline $\begin{array}{l}\text { Fletcher } \\
\text { 1997) }\end{array}$ & 11 & DC pulsed & NP & 500 & 10 \\
\hline $\begin{array}{c}\text { (Wilkins et al. } \\
\text { 1998) }\end{array}$ & $\begin{array}{l}87-117 \\
90-157\end{array}$ & $\begin{array}{l}\text { DC pulsed, retified sinewave } \\
\text { AC sinewave, clipped }\end{array}$ & $\begin{array}{c}104-111 \\
105\end{array}$ & $\begin{array}{c}100,500 \\
1500 \\
50\end{array}$ & 4 \\
\hline $\begin{array}{l}\text { (Raj and } \\
\text { O'Callaghan } \\
\text { 2004a) }\end{array}$ & Pico 620 & AC sinewave & $\begin{array}{l}100 \\
150\end{array}$ & $50,400,1500$ & 1 \\
\hline $\begin{array}{c}\text { (Xu et al. } \\
\text { 2011) }\end{array}$ & $35,50,65$ & AC sinewave & $\begin{array}{l}47,67 \\
86\end{array}$ & $\begin{array}{l}160,400 \\
1000\end{array}$ & 15 \\
\hline \multirow{3}{*}{$\begin{array}{l}\text { (Prinz et al. } \\
\text { 2012) }\end{array}$} & 60 & AC sinewave & 50 & 50 & \multirow{3}{*}{4} \\
\hline & 80 & $\mathrm{AC}$ rectangular & 70 & 90 & \\
\hline & 120 & DC pulsed & 70 & 130 & \\
\hline
\end{tabular}

$141 \mathrm{NP}$ - not provided; AC - alternative current; $\mathrm{DC}$ - direct current

142 
bioRxiv preprint doi: https://doi.org/10.1101/2021.08.02 454822; this version posted August 5,2021 The copyright holder for this preprint (which was not certified by peer review) is the author/funder, who has granted bioRxiv a license to display the preprint in perpetuity. It is made available under aCC-BY-NC-ND 4.0 International license.

Electrical hybrid-frequency in animal welfare

\section{EEG response in electrically stunned chickens}

Digital processing of the EGG data reveal that $100 \%$ of the birds, at the exit of the

148 electrical water bath, had an epileptic form followed by a quiescent pattern. This pattern lasted

149 until the moment of bleeding, presenting no EEG pattern compatible with return of 150 consciousness; i.e., after bleeding the EEG evolved to an isoelectric pattern. In addition, the 151 data show that no bird had brain death before cutting. process of one of the birds, randomly selected. The same phenomenon occurred in all birds sampled.
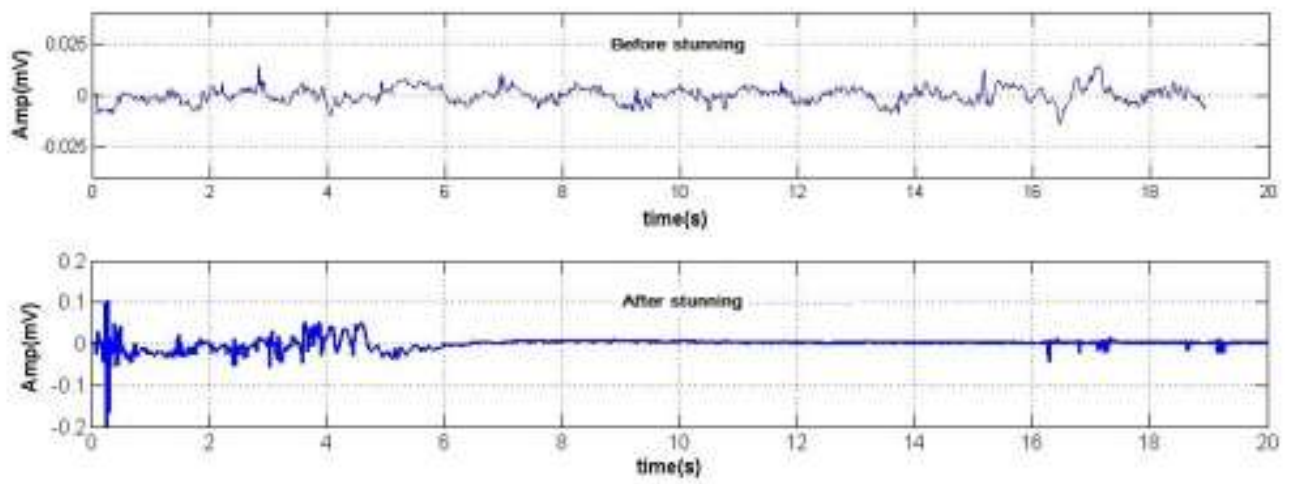

Figure 3 - EEG pattern before and after Stunning process

For all acquired EEG signals, the signal Power Spectral Density (PSD) was calculated using the Welch Method (Manshouri et al., 2018). PSD displays the power distribution among

159 the frequency components. Epileptic events have a different frequency distribution than normal 160 brain signals, characterized mainly by an increase in frequency. Figure 4 shows the PDS calculated for EEG before and after stunning for a $95 \%$ confidence interval. 


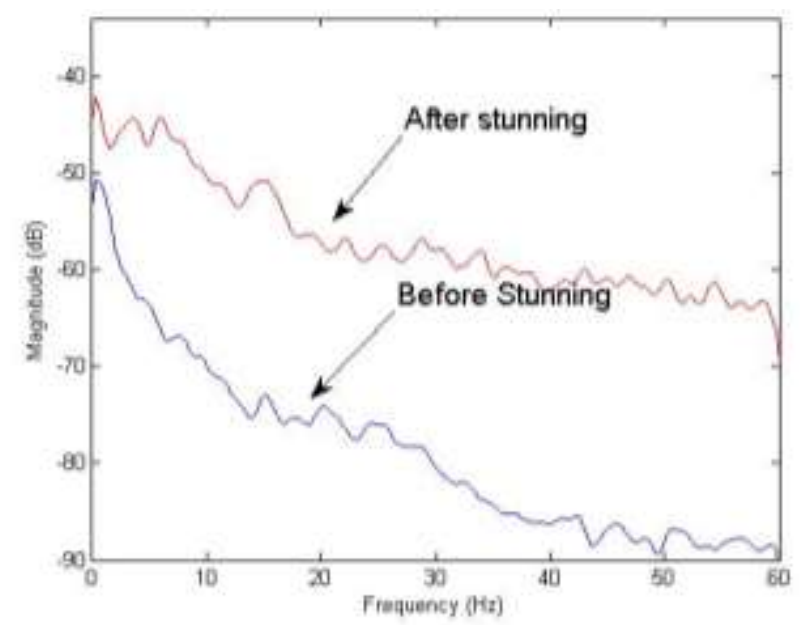

The graphic record of the variation in the amplitude of the electrical brain activity based on time is an EEG.

The electric brain signals show features that distinguish them from other biological (EFSA), efficient stunning methods disrupt the neurons or neurotransmitter regulatory mechanisms in the brain, causing a long-lasting depolarized neuronal state that renders animals unconscious and insensible (EFSA 2004). The EEG is the most reliable indicator of the unconsciousness and insensibility of the birds, since somatosensory reflexes and direct observations are not sufficiently reliable indicators of insensibility at high frequencies (EFSA 2013).

The use of signal processing techniques represent an important tool for identifying

177 patterns on the EEG. The employment of digital processing methods for signals allows for more

178 information to be obtained from the EEG signals than is obtained in its representation in the 179 form of a time series. These processing methods include Fourier analysis, time-frequency, non180 linear models, as well as the theory of complex systems and wavelets (Marchant, 2003). As 
bioRxiv preprint doi: https://doi.org/10.1101/2021.08.02 454822; this version posted August 5,2021 The copyright holder for this preprint (which was not certified by peer review) is the author/funder, who has granted bioRxiv a license to display the preprint in perpetuity. It is made available under aCC-BY-NC-ND 4.0 International license.

\section{Electrical hybrid-frequency in animal welfare}

181

182

183

184

185

186

187

188

189

190

191

192

193

194

195

196
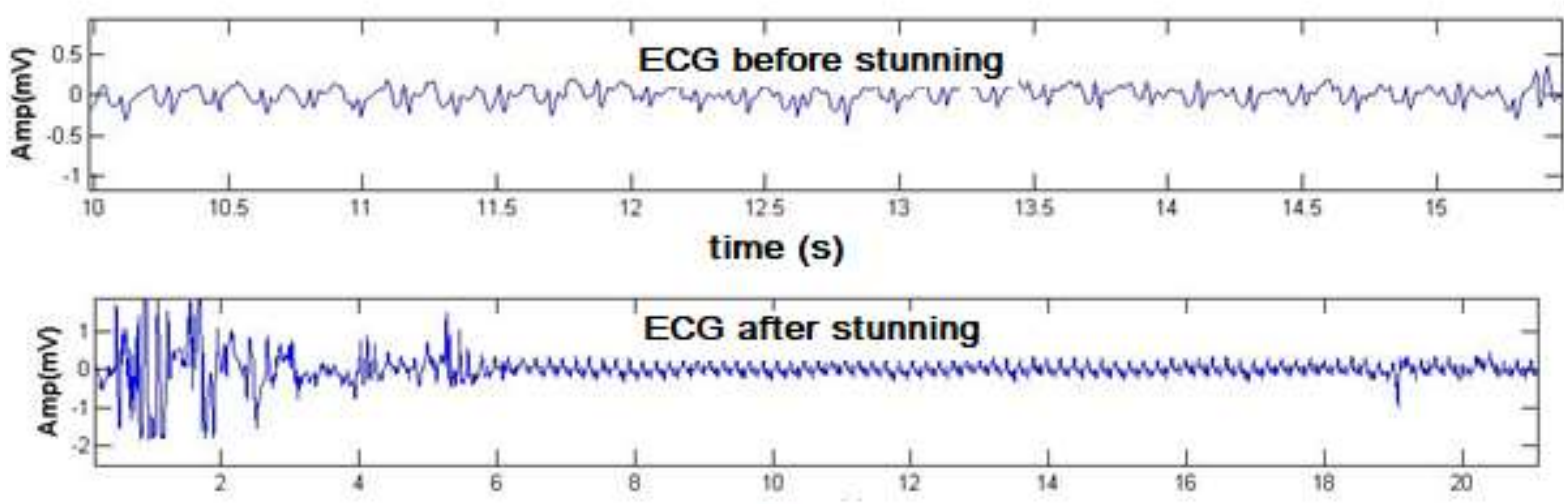

197

198

seen in Figure 4, when the data are transformed, the frequencies and their magnitudes are more prominent, and the differences between before and after stunning can be better quantified.

\section{ECG response in electrically stunned chickens}

The ECG measurement is an important physiological measurement to analyze broilers' behavior (Blanchard et al., 2002). Actually, ECG had been used mainly to monitor broilers under Low Atmospheric Pressure Stunning (LAPS) methods (Martin et al., 2016), and few studies have been conducted on electrical water bath stunning methods. Notwithstanding, ECG can be used to monitor the broilers' heart rates before and after electrical stunning (Barbosa et al., 2016).

After the ECG data were digitally processed, it was revealed that $100 \%$ of the birds were alive until bleeding. The ECG allowed the correct measuring frequencies of the birds' heartbeats before and after the passage of the stunning electric current (Figure 5). Figure 5 shows the electrical activity of the heart, before and after the stunning process, of one of the birds randomly selected from the experimental runs.

\section{time (s)}


The signals shown in Figure 5 were collected from the time the bird left the electrical water bath, i.e. just after the stunning process, and continued until after bleeding. The ECG pattern shows that, after the passage of the electric current, the heart rate, although altered in relation to frequency and amplitude, continued to represent an electrically active heart until the cut performed by the bleeder.

As suggested by other studies (Raj and O'Callaghan, 2004a; Raj et al,. 2006a), the depth of desensitization can be related to the pulse width time. In this case, the use of a hybrid207 frequency electrical current, respecting the proportion of the single wave duty-cycle, may have contributed to obtaining increased levels of current. In living tissue, there are free ions in extracellular fluids, where the electrical current finds less resistance to flow. The lipid and 210 protein components of living tissues offer more resistance to the passage of electrical currents, 211 and different parameter configurations of an electrical current could change their conductivity. 212 For example, the increase of electric current frequency has been shown to raise the conductivity 213 of living tissues (Gabriel, 1996).

215 verified by various studies (Gregory and Wotton, 1991; Wilkins et al., 1998; Xu et al., 2011;

216 Huang et al., 2014), the use of a hybrid frequency wave system results in a positive effect on 217 meat quality, without negatively affecting the animal's welfare. However, concerning animal 218 welfare, a very important question is whether loss of consciousness occurs instantly in electrical 219 stunning.

The occurrence of highly synchronized $8-13 \mathrm{~Hz}$ activity in EEG recordings, as well 221 as the absence of potential somatosensory evoked responses are known as reliable 222 measurements to determine the effectiveness of stunning methods (Berg and Raj, 2015; 223 Terlouw et al., 2015). In a study using different electrical single stunning frequencies, 
225 (Raj and O'Callaghan, 2004a) was observed. Despite some initial disagreement regarding the 226 occurrence of generalized epilepsy in poultry (Gregory and Wotton, 1987; Gregory and Wotton, 227 1989; Raj, 2003), further research confirmed that effective electrical stunning of chickens 228 indeed leads to epileptiform EEG activity compatible with an unconscious state (Raj and 229 O’Callaghan, 2004b; Raj et al., 2006a; Raj et al., 2006b).

To the best of the authors' knowledge, there is no information on the brain activity of 231 broilers at the exact moment of electrical shock. The published studies report brain activity right 232 after the electrical shock. The scientific knowledge about human electroconvulsive therapy 233 without the use of anaesthetics, which includes reports of intensive pain by patients, was used 234 in a critical comparison to the electrical stunning of broilers (Zivotofsky and Strous, 2012). 235 Unfortunately, even in methods where animals recover after the procedure, an animal cannot express whether it had experienced pain during the electrical shock, and there is no technology available to date to answer this question. frequencies $(50 / 60 \mathrm{~Hz})$ are more effective, and when high frequencies are used, the amount of 240 electrical current must be increased to maintain the effectiveness of stunning (Gregory and 241 Wotton, 1991; Wilkins et al., 1998; Raj et al., 2006a; Prinz et al., 2010a; Prinz et al., 2010b; 242 Prinz et al., 2012). Regarding meat quality, higher frequencies have shown a positive effect 243 with a decrease of broken bones and hemorrhagic spot indices in many species (Anil and 244 McKinstry, 1992; Turcsán et al., 2003; Xu et al., 2011; Grimsbø et al., 2014; Robins et al., 245 2014; Huang et al., 2014). 
CONCLUSIONS AND APPLICATIONS

The results of the experiments conducted at slaughterhouse of Copacol (Cafelândia -

252 PR) with the hybrid-frequency wave current generator, using the stunning equipment UFX7 253 Solution ${ }^{\circledR}$ support the following conclusions:

- Humanitarian slaughter: $100 \%$ of the birds that underwent electrical shock presented generalized epilepsy after being submitted to the pre-established electrical standards of the

European Union and OIE. This conclusion is supported by clinical analysis and EEG data analysis.

- Religious slaughter - Halal: $100 \%$ of the birds were still alive after the electric shock according to the EEG and ECG data, as well as clinical signs. There was no impact on the killing or bloodletting process. The use of hybrid-frequency current is effective to promote humanitarian and Halal slaughter, guaranteeing epilepsy followed by a quiescence period, and keeping animals alive after desensitization. In addition, equipment with an effective

\section{Acknowledgment}

269 The authors would like to thanks to Prof.. JaciMara Baptista and Ms. Madariaga-Hopkins

270 from UNLV-USA for English revision. 
bioRxiv preprint doi: https://doi.org/10.1101/2021.08.02 454822; this version posted August 5 , 2021. The copyright holder for this preprint (which was not certified by peer review) is the author/funder, who has granted bioRxiv a license to display the preprint in perpetuity. It is made available under aCC-BY-NC-ND 4.0 International license.

Electrical hybrid-frequency in animal welfare

\section{REFERENCES}

276

277

278

279

280

281

282

283

284

285

286

287

288

289

290

291

292

293

294

295

296

297

298

299

300

301

302

303

304

305

306

307

308

309

310

311

312

313

314

315

316

317

318

319

320

321

322

Anil MH, McKinstry JL (1992) The effectiveness of high frequency electrical stunning in pigs. Meat Science 31, 481-491. doi:10.1016/0309-1740(92)90030-8.

Berg C, Raj M (2015) A Review of Different Stunning Methods for Poultry - Animal Welfare Aspects (Stunning Methods for Poultry). Animals 5, 1207-1219. doi:10.3390/ani5040407.

Blanchard S, Degernes L, DeWolf D, Garlich J (2002) Intermittent biotelemetric monitoring of electrocardiograms and temperature in male broilers at risk for sudden death syndrome. Poultry Science 81, 887-891. doi:10.1093/ps/81.6.887.

Craig E, Fletcher D (1997) A comparison of high current and low voltage electrical stunning systems on broiler breast rigor development and meat quality. Poultry Science 76, 1178-1181. doi:10.1093/ps/76.8.1178.

EFSA (2004) Opinion of the Scientific Panel on Animal Health and Welfare (AHAW) on a request from the Commission related to welfare aspects of the main systems of stunning and killing the main commercial species of animals. EFSA Journal 2, 45. doi:10.2903/j.efsa.2004.45.

EFSA (2013) Annual Report of the EFSA Journal 2012. EFSA Supporting Publications 10,. doi:10.2903/sp.efsa.2013.EN-418.

European Union Council (2009) 'Regulamento (CE) N. o 1099/2009 do Conselho da União Européia de 24 de Setembro de 2009 relativo à proteção dos animais no momento da occisão.'

Gabriel SG and RWL and C (1996) The dielectric properties of biological tissues: II. Measurements in the frequency range $10 \mathrm{~Hz}$ to $20 \mathrm{GHz}$. Physics in Medicine and Biology 41, 2251.

Gregory NG, Wotton SB (1987) Effect of electrical stunning on the electroencephalogram in chickens. The British veterinary journal 143, 175-183. doi:10.1016/0007-1935(87)90009-1.

Gregory NG, Wotton SB (1989) Effect of electrical stunning on somatosensory evoked potentials in chickens. British Veterinary Journal 145, 159-164. doi:10.1016/0007-1935(89)90098-5.

Gregory NG, Wotton SB (1991) Effect of a $350 \mathrm{~Hz}$ DC stunning current on evoked responses in the chicken's brain. Research in veterinary science 50, 250-251. doi:10.1016/0034-5288(91)90118-8.

Grimnes S, Martinsen ØG (2015) Chapter 1 - Introduction BT - Bioimpedance and Bioelectricity Basics (Third Edition). pp. 1-7. (Academic Press: Oxford) doi:http://dx.doi.org/10.1016/B978-0-12-411470-8.00001-5. 
bioRxiv preprint doi: https://doi.org/10.1101/2021.08.02 454822; this version posted August 5,2021 . The copyright holder for this preprint (which was not certified by peer review) is the author/funder, who has granted bioRxiv a license to display the preprint in perpetuity. It is made available under aCC-BY-NC-ND 4.0 International license.

Electrical hybrid-frequency in animal welfare

323

324

325

326

327

328

329

330

331

332

333

334

335

336

337

338

339

340

341

342

343

344

345

346

347

348

349

350

351

352

353

354

355

356

357

358

359

360

361

362

363

364

365

366

367

368

369

370

371

Grimsbø E, Nortvedt R, Hammer E, Roth B (2014) Preventing injuries and recovery for electrically stunned Atlantic salmon (Salmo salar) using high frequency spectrum combined with a thermal shock. Aquaculture 434, 277-281. doi:10.1016/j.aquaculture.2014.07.018.

Huang JC, Huang M, Yang J, Wang P, Xu XL, Zhou GH (2014) The effects of electrical stunning methods on broiler meat quality: Effect on stress, glycolysis, water distribution, and myofibrillar ultrastructures. Poultry Science 93, 20872095. doi:10.3382/ps.2013-03248.

Manshouri N, Maleki M, Kayikcioglu T (2018) Power spectrum analysis of EEG for watching 2D \&amp; 3D videos and resting state. In '2018 26th Signal Process. Commun. Appl. Conf.', 1-4. (IEEE) doi:10.1109/SIU.2018.8404394.

Marchant BP (2003) Time-frequency Analysis for Biosystems Engineering. Biosystems Engineering 85, 261-281. doi:10.1016/S1537-5110(03)00063-1.

Martin JE, Christensen K, Vizzier-Thaxton Y, McKeegan DEF (2016) Effects of light on responses to low atmospheric pressure stunning in broilers. British Poultry Science 1-16. doi:10.1080/00071668.2016.1201200.

OIE (2019) 'Terrestrial Animal Health Code 2019. Volume 1 : General provisions.' (@) OIE (World Organisation for Animal Health)) https://www.oie.int/standardsetting/terrestrial-code/.

Prinz S, Van Oijen G, Ehinger F, Bessei W, Coenen a (2010) Effects of waterbath stunning on the electroencephalograms and physical reflexes of broilers using a pulsed direct current. Poultry Science 89, 1275-1284. doi:10.3382/ps.200900136.

Prinz S, Van Oijen G, Ehinger F, Bessei W, Coenen a. (2012) Electrical waterbath stunning: Influence of different waveform and voltage settings on the induction of unconsciousness and death in male and female broiler chickens. Poultry Science 91, 998-1008. doi:10.3382/ps.2009-00137.

Prinz S, Van Oijen G, Ehinger F, Coenen A, Bessei W (2010) Electroencephalograms and physical reflexes of broilers after electrical waterbath stunning using an alternating current. Poultry Science 89, 1265-1274. doi:10.3382/ps.2009-00135.

Raj a BM (2003) A critical appraisal of electrical stunning in chickens. World's Poultry Science Journal 59, 89-98. doi:10.1079/WPS20030005.

Raj ABM, O'Callaghan M (2004a) Effect of amount and frequency of head-only stunning currents on the electroencephalogram and somatosensory evoked potentials in broilers. Animal Welfare 13, 159-170.

Raj a BM, O'Callaghan M (2004b) Effects of electrical water bath stunning current frequencies on the spontaneous electroencephalogram and somatosensory 
bioRxiv preprint doi: https://doi.org/10.1101/2021 08.02.454822; this version posted August 5 , 2021. The copyright holder for this preprint (which was not certified by peer review) is the author/funder, who has granted bioRxiv a license to display the preprint in perpetuity. It is made available under aCC-BY-NC-ND 4.0 International license.

Electrical hybrid-frequency in animal welfare

evoked potentials in hens. British poultry science 45, 230-236. doi:10.1080/00071660410001715830.

Raj ABM, O'Callaghan M, Knowles TG (2006a) The effects of amount and frequency of alternating current used in water bath stunning and of slaughter methods on electroencephalograms in broilers. Animal Welfare 15, 19-24.

Raj ABM, O'Callaghan M, Knowles TG (2006b) The effects of pulse width of a direct current used in water bath stunning and of slaughter methods on spontaneous electroencephalograms in broilers. Animal Welfare 15, 25-30.

Robins a., Pleiter H, Latter M, Phillips CJC (2014) The efficacy of pulsed ultrahigh current for the stunning of cattle prior to slaughter. Meat Science 96, 1201-1209. doi:10.1016/j.meatsci.2013.10.030.

De Sousa Silva AC, Céspedes Arce AI, Souto S, Xavier Costa EJ (2005) A wireless floating base sensor network for physiological responses of livestock. Computers and Electronics in Agriculture 49,. doi:10.1016/j.compag.2005.05.004.

Terlouw C, Bourguet C, Deiss V (2015) Consciousness, unconsciousness and death in the context of slaughter. Part II. Evaluation methods. Meat Science. doi:10.1016/j.meatsci.2016.03.010.

Turcsán Z, Varga L, Szigeti J, Turcsán J, Csurák I, Szalai M (2003) Effects of electrical stunning frequency and voltage combinations on the presence of engorged blood vessels in goose liver. Poultry science 82, 1816-1819.

Wilkins LJ, Gregory NG, Wotton SB, Parkman ID (1998) Effectiveness of electrical stunning applied using a variety of waveform-frequency combinations and consequences for carcase quality in broiler chickens. British poultry science 39, 511-518. doi:10.1080/00071669888692.

Xu L, Zhang L, Yue HY, Wu SG, Zhang HJ, Ji F, Qi GH (2011) Effect of electrical stunning current and frequency on meat quality, plasma parameters, and glycolytic potential in broilers. Poultry science 90, 1823-1830. doi:10.3382/ps.2010-01249.

Zivotofsky AZ, Strous RD (2012) A perspective on the electrical stunning of animals: Are there lessons to be learned from human electro-convulsive therapy (ECT)? Meat Science 90, 956-961. doi:10.1016/j.meatsci.2011.11.039. 